\title{
Drought Affects the Antioxidant System and Stomatal Aperture in Zanthoxylum
}

Xitong Fei ${ }^{1,2}$, Haichao $\mathrm{Hu}^{1,2}$, Jingmiao $\mathrm{Li}^{1,2}$, Yulin $\mathrm{Liu}^{1,2}$, Anzhi Wei ${ }^{1,2, *}$

${ }^{1}$ College of Forestry, Northwest A\&F University, Yangling, Shaanxi, China

$10{ }^{2}$ Research Centre for Engineering and Technology of Zanthoxylum State Forestry Administration, 11 Yangling, Xianyang 712100, China

* Corresponding author:E-mail: Weianzhi@126.com

\section{Abstract}

When under drought, plants activate a range of self-protective responses. Among these are activation of the antioxidant system and changes in stomatal aperture. The antioxidant system can remove the reactive oxygen species produced under drought conditions and so mitigate oxidative damage. Water becomes a severely limiting resource for plants suffering drought stress, so they generally close their stomata to reduce water loss. We examined changes in the activities of the antioxidant enzymes and altered gene expression patterns in Zanthoxylum bungeanum plants exposed to drought by irrigation

21 with 20\% PEG6000. We also recorded changes in stomatal aperture as the drought persisted.

22 Relationships between the antioxidant system and stomatal aperture were analyzed in relation to gene expression. The results indicate that under drought stress, POD, CAT, APX, proline, MDA and 
related genes all show positive responses to drought, while SOD and its genes showed a negative response. The relationship between drought duration and stomatal aperture was considered. Stomatal aperture declines exponentially as drought duration increases.

\section{Introduction}

Zanthoxylum bungeanum Maxim. (common name Chinese prickly ash, family Rutaceae) is widely distributed in Asia [1] where it is an important economic crop. Evolution and natural selection have led the epidermis of $Z$. bungeanum to bear prickles. This species also has strong drought adaptability. The skin of $Z$. bungeanum is the source of one of the eight traditional Chinese condiments, so this plant plays a very important role in Chinese food culture. Because of its unique numbing taste, $Z$. bungeanum is difficult to replace with other seasonings [2]. It has become an important component of the diet in various parts of Asia, especially in China. Zanthoxylum bungeanum and pepper become best companions and are together an important part of the 'hot pot' culture. In addition to its use as a food seasoning, the skin of $Z$. bungeanum also contains chemical components showing proven medicinal properties, including bactericidal [3], insecticidal [4], antioxidant [2] and topical anesthetic [5].

Drought stress can cause a series of physiological and molecular reactions in plants, which seriously affect normal growth. Thus, drought can cause imbalances in cellular reactive oxygen species (ROS), it can also upset cell membrane lipid peroxidation and it can damage cell and organelle membranes. Excessive ROS have toxic effects on plants. Irrigated agriculture is not yet general, so drought remains one of the most important unfavorable factors affecting both the yield and quality of most commercial crops. Plants have many protective responses to maintain metabolic 


\section{Materials and methods} resist drought $[12,13]$.

\section{Materials}

stability and so continue life under environmental stress. Their antioxidant systems are able to produce a variety of antioxidant enzymes - including superoxide dismutase, peroxidase, antioxidant enzymes, ascorbate peroxidase - to combat the ROS produced under drought stress $[6,7]$. For example, catalase can decompose $\mathrm{H}_{2} \mathrm{O}_{2}$ produced in plants to form water and oxygen, reducing or eliminating damage by this ROS [8]. The antioxidant system also maintains organelle stability, preventing damage to the chloroplast membrane and so stabilizing the PSII system [9]. In addition, stomata are important gas exchange organs of plants, playing irreplaceable roles in the regulation of photosynthesis, respiration, transpiration and temperature [10, 11]. The stomata are also the water-regulating organs of plants. Under drought, water conservation becomes the decisive factor for plant survival. The response of stomata to drought is also a way for plants to protect themselves. Under drought stress, plants reduce water loss by stomatal closure and so increase their ability to

The impact of drought on the yield and quality of $Z$. bungeanum is huge and seriously hinders the development of this industry. The detailed responses of the antioxidant system and of the stomata of $Z$. bungeanum to drought stress remain unclear. Hence a study of their behavior under drought stress, will have significance for better understating this species' drought-resistance mechanisms. It can also provide a basis for drought-resistant breeding of $Z$. bungeanum and of related species.

The Z. bungeanum seeds were collected from the Fengxian Chinese prickly ash Experimental Station of Northwest Agriculture and Forestry University. They were germinated and cultured in an 
artificial climate chamber at $25 \pm 2^{\circ} \mathrm{C}$. Air humidity was set to $80 \%$ and the photoperiod to $16: 8 \mathrm{~h}$

(light:dark). Three-month-old seedlings were used as experimental material. Zanthoxylum

bungeanum seedlings were then cultured in half-strength Murashige and Skoog (MS) liquid medium

containing 20\% PEG6000. Leaf samples were collected and stored in liquid nitrogen after periods of

$0,3,6,12,24,36$ and $48 \mathrm{~h}$.

\section{Methods}

\section{Physiological index determination}

The leaf samples after different periods of drought stress were used to determine antioxidant

enzyme activity and malondialdehyde (MDA) and proline contents. Superoxide dismutase (SOD)

activity was determined by the nitroblue tetrazolium method [7]. Peroxidase (POD) activity was

determined by the guaiacol method and catalase (CAT) activity was determined by the hydrogen

peroxide ultraviolet method [8]. For APX (L-ascorbate peroxidase) activity we used the method of

Panchuk et al [14]. The MDA content was determined by the thiobarbituric acid (TBA) method [15].

81 Proline was determined by ninhydrin colorimetry [16].

\section{Total RNA extraction}

Total RNA of the $Z$. bungeanum samples was extracted using the TaKaRa MiniBEST Plant

RNA Extraction Kit (TaKaRa, Beijing, China) following the manufacturer's instructions. The purity

and concentration of the RNA obtained were measured using NanoDrop 20000 (Thermo Scientific,

Pittsburgh, PA, USA). Only samples where the OD260/280 value was $1.8-2.0$ and the OD260/230

value was higher than 2.0 were used for cDNA synthesis.

\section{Quantitative Real-time PCR}


91 (Bio-Rad, Hercules, CA, USA). The reaction system was of $10 \mu 1$, containing $5 \mu 1$ of $2 \times$ SYBR

92 Premix Ex Taq II (TaKaRa), $1 \mu \mathrm{l}$ of cDNA, $1 \mu \mathrm{l}$ of each of the upstream and downstream primers and $2 \mu \mathrm{l}$ of $\mathrm{ddH}_{2} \mathrm{O} . \mathrm{ZbUBQ}$ and $Z b \alpha-E F$ were used for the reference genes to correct the RT-qPCR

94 data [17].

95 Table 1. RT-qPCR primers

\begin{tabular}{|c|c|c|c|}
\hline Name & Description & Forward primer sequence ( $\left.5^{\prime}-3^{\prime}\right)$ & Reverse primer sequence (5'-3') \\
\hline SOD1 & $\begin{array}{l}\text { Superoxide dismutase }[\mathrm{Mn}] \quad 1 \text {, } \\
\text { mitochondrial }\end{array}$ & CAGCGTCTCACATCATTTCATTT & TCTTCAGTCCACGTAGCCCTAGT \\
\hline SOD2 & $\begin{array}{l}\text { Superoxide dismutase }[\mathrm{Fe}] \text {, } \\
\text { chloroplastic-like isoform X2 }\end{array}$ & GGGATTACTCACСТCTCCTTACC & тССТСТТСТСТТТТССТССТТТС \\
\hline$P R X 2 E$ & Peroxiredoxin-2E, chloroplastic (POD) & AATCAAAAGGCATCGACACCA & АСТССССАТТСССАТСАGACA \\
\hline$C A T$ & Catalase isozyme 1 (CAT) & TTTCCCTGTCTTCTTCATCCGT & TCCTTCCATGTGCCTGTAATCT \\
\hline$A P X 3$ & L-ascorbate peroxidase 3 & GCCTTCCAGATGCCAAACAA & CCCCCTGAGAGTGCCACTAT \\
\hline$G P X 1$ & $\begin{array}{l}\text { Phospholipid hydroperoxide glutathione } \\
\text { peroxidase 1, chloroplastic (GPX1) }\end{array}$ & CAAGTGCTGGGGGATTTTTA & ATGGTGATGTTGTTGGTGGA \\
\hline P5CS & $\begin{array}{l}\text { Delta-1-pyrroline-5-carboxylate synthase. } \\
\text { Key enzyme for the synthesis of proline }\end{array}$ & $\begin{array}{l}\text { AGCAAAACACCAAGCAGAAATA } \\
\text { A }\end{array}$ & $\begin{array}{l}\text { AATAACAGGGATACCAGCATAA } \\
\text { G }\end{array}$ \\
\hline JAR1 & $\begin{array}{l}\text { Jasmonic acid-amido synthetase JAR1, } \\
\text { participate in the synthesis of jasmonic } \\
\text { acid }\end{array}$ & CTCGGAAGCAGCAGCCAAACT & AGCAAAGGAGCAATCCAAACA \\
\hline
\end{tabular}




\begin{tabular}{|c|c|c|c|}
\hline$A B I$ & $\begin{array}{l}\text { ABSCISIC ACID-INSENSITIVE 5-like } \\
\text { protein 5. Key nodes and inhibitors of the } \\
\text { abscisic acid (ABA) signaling pathway } \\
\text { regulate a variety of ABA responses, such } \\
\text { as stomatal closure, plasma membrane } \\
\text { permeability and water permeability. }\end{array}$ & TGTCTCCAGTTCCTTACATGTTT & CTTGCTGCTGACTCTCTATTCTT \\
\hline$M A P K 1$ & Mitogen-activated protein kinase 1 & CTAАСТСТААСССТССАGCССАG & TTTCGTTCCACATCATTTCCCTT \\
\hline PDI52 & $\begin{array}{l}\text { Protein disulfide-isomerase } 5-2 \text { isoform } \\
\mathrm{X} 1\end{array}$ & AGAGAAGGAAGAACCGAAAA & GAAGTGCCAACACTGAGAGG \\
\hline $\mathrm{RBOHC}$ & $\begin{array}{l}\text { Respiratory burst oxidase homolog protein } \\
\text { C [Citrus sinensis] }\end{array}$ & GGCACCCATTTTCAATAA & GCTCTGAGGAGTCCACTT \\
\hline$N R X 1$ & Probable nucleoredoxin 1 & TGAAGCCATCGAAGAACAC & ССССТААААССАAАACAGA \\
\hline EPFL9 & $\begin{array}{l}\text { EPIDERMAL PATTERNING } \\
\text { FACTOR-like protein } 9\end{array}$ & СТССТССТАСТАСТССТТGСТ & AATACCTTTGCTTCACTGCTT \\
\hline TCTP & $\begin{array}{l}\text { Translationally-controlled tumor protein } \\
\text { homolog; Involved in the regulation of } \\
\text { abscisic acid- and calcium-mediated } \\
\text { stomatal closure }\end{array}$ & TCTCTCAGACTCGTTTCCCTAC & CTCCTTGAACAACCCACTTTCC \\
\hline$N O X$ & NADPH oxidase & CTGGTGGATCTGATATTGGAGTA & AGAGGGTGGAAACCGAAGTA \\
\hline$Z b U B Q$ & $\begin{array}{l}\text { Zanthoxylum bungeanum ubiquitin } \\
\text { extension protein, reference gene }\end{array}$ & TCGAAGATGGCCGTACATTG & TCCTCTAAGCCTCAGCACCA \\
\hline
\end{tabular}




\begin{tabular}{|l|l|l|l|}
\hline$Z b \alpha-E F$ & Zanthoxylum bungeanum Elongation & GTGCTTGACTGCCACACCTC & TTCCGGCATCTCCATTCTTC \\
& factor 1-alpha, reference gene & & \\
\hline
\end{tabular}

\section{Stomatal observation}

The nail-polish method was used to observe the state of the stomata on the leaves. Nail polish was applied to the abaxial surfaces of $Z$. bungeanum leaves after different periods of drought stress, air-dried, peeled off and examined under a light microscope (Olympus Provis AX70 microscope, stomata were randomly selected for each period to measure stomatal aperture.

\section{Results}

\section{Physical substance detection}

Changes in the levels of protective substances and genes in antioxidant system were monitored

follow the same general pattern - their activities increased under continuing drought stress and also increased with drought duration. 


\section{Molecular level detection}

The expression patterns of genes related to the antioxidant system were essentially consistent with the changes in the related substances. Genes such as PRX2E, CAT, APX3, P5CS and GPXI showed a significant increase under drought stress (Figure 2). The expression levels of the SOD gene in chloroplasts and mitochondria were monitored and we found the SOD2 gene in the chloroplast was positively correlated with superoxide dismutase activity. The SOD1 gene in mitochondria was negatively correlated with the activity of superoxide dismutase. It is concluded that the superoxide dismutase produced by Z. bungeanum under drought stress comes mainly from the chloroplast.

Figure 2. Heat map of gene expressions relating to the antioxidant system and stomatal aperture.

Some further gene expression patterns with drought stress and stomatal movement were also monitored. P5CS is a key enzyme in the proline synthesis process. $A B I$ is a key inhibitor of the ABA signaling pathway and participates in the closure of stomata and TCTP is involved in ABA and calcium ion-mediated stomatal closure. In addition, the relative expression levels of MAPK1 and PDI52 were also up-regulated (Figure 3). At the same time, the relative expression of JAR1, a gene related to jasmonic acid synthesis, was also up-regulated under the induction of drought stress. However, other genes were inhibited, such as RBOHC, NRX1, EPFL9.

Figure 3. Relative expression levels of genes related to antioxidant system and stomatal aperture under continuing drought stress.

\section{Stomatal opening}


The numbers of stomata on the abaxial leaf surfaces of $Z$. bungeanum were counted and

stomatal dimensions were measured. Average stomatal density was found to be $850.87 \mathrm{~mm}^{-2}$.

140 Average guard cell length was $13.51 \mu \mathrm{m}$ and width was $8.95 \mu \mathrm{m}$. Average length of the stomatal pores was $17.03 \mu \mathrm{m}$ and their maximum width (aperture) was $7.45 \mu \mathrm{m}$ (see Figure 4).

Figure 4. Stomatal movement of Zanthoxylum bungeanum under drought stress. at different stages of drought stress was measured.

Figure 5. Trend of stomatal width with drought stress duration. at which the stomata are closed. With increasing drought stress duration, stomatal aperture gradually rapid, and this rate decreased with time.

\section{Discussion}

The results show that most of antioxidant enzymes trend upward under continuing drought 
160 chloroplasts are consistent, which indicates the chloroplast antioxidant system was severely damaged

161 during the drought. In addition, it can be explained that in the antioxidant system, several other antioxidant enzymes (such as POD, CAT, APX) exert major antioxidant effects. Proline and MDA increased gradually during the drought stress and may also be involved in signal transduction and protection. Studies have shown that Barbula fallax and pepper have similar patterns of antioxidant enzyme activity, where SOD showed a downward trend in the early stage of drought stress, while POD and CAT activities were positive in response to drought stress and increased in the early stage of drought stress [19]. In many species, the activities of antioxidant enzymes such as SOD, POD, CAT, and APX generally rise under drought. Chickpea accumulates proline and increases the activity of SOD, APX, GPX and CAT under drought stress [20]. The activities of SOD, POD and CAT in alfalfa increase significantly under drought stress [21]. This also occurs in pea [22], rice [23], Kentucky bluegrass [24] and sesame [25].

\section{Relationship between antioxidant signaling pathway and stomatal aperture} the oxidative system and stomatal aperture. 

species can destroy cell membranes and interfere with normal growth of plants, while the accumulation of ROS is toxic to plants. ABA binds to the promoter of RBOHC and promotes the production of respiratory burst oxidase (NADPH oxidase) [26]. NADPH oxidase (NOX) also activates $\mathrm{Ca}^{2+}$ channels on the cell membrane [27]. In addition, it has been shown to play an important protective role in plant drought stress, preventing leaves from being destroyed by ROS [28, 29]. The production of ROS activates the plant's antioxidant system. SOD, POD, CAT, APX, GPX and other enzymes can convert superoxide anion to $\mathrm{H}_{2} \mathrm{O}_{2}$ and eventually decompose it into non-toxic $\mathrm{H}_{2} \mathrm{O}$ and $\mathrm{O}_{2}[28,30]$. The antioxidant system decomposes ROS to produce $\mathrm{H}+$, which provides a substrate for glutamate synthesis in the proline pathway. At the same time, plants can also synthesize ABA under drought stress, and ABA can promote the synthesis of proline from glutamate, which eventually leads to a large accumulation of proline [31]. Proline is an important osmotic adjustment substance in plants, so the above reaction is beneficial, allowing plants to cope better with drought. and there is close interaction between them $[32,33]$. On the one hand, ABA can promote the synthesis of CAT and improve the efficiency of the antioxidant system. While, on the other hand,

199 GPX1 can inhibit ABI, thereby relieving the inhibition of ABA by plants [34]. The accumulation of 200 ROS can activate the $\mathrm{Ca}^{2+}$ channel on the cell membrane, causing a large amount of $\mathrm{Ca}^{2+}$ to enter the cell, and so can increase the $\mathrm{Ca}^{2+}$ concentration of the guard cells and change their osmotic potential [35]. At the same time, high concentration of $\mathrm{Ca}^{2+}$ can suppress the input of $\mathrm{K}^{+}$and the output of $\mathrm{H}^{+}$. 
204 in the membrane. The combination of ABA and TCTP can induce stomatal closure, and CPK can phosphorylate CAT as well as promote stomatal closure [37].

EPFL9 is a gene related to stomatal development. Our results show that its relative expression

207 decreased under drought stress, which indicates stomatal development slows or stops under drought

stress. During the scavenging of $\mathrm{H}_{2} \mathrm{O}_{2}$ by antioxidant enzymes, it is susceptible to oxidative stress,

resulting in reduced clearance. NRX1 is able to reduce oxidized antioxidant enzymes and has a stable

antioxidant system [38]. However, in the gene expression level study, the expression level of NRXI

was down-regulated. It is concluded that drought interfered with the reduction of NRX1 against oxidase.

In summary, the plant's antioxidant system and stomatal aperture play important roles in

responding to drought stress, which helps with survival. By analyzing the regulatory relationships,

we show there is a close relationship between the antioxidant system and stomatal aperture. On the one hand, the antioxidant system can act as a signal to regulate stomatal aperture, while, on the other, stomatal closure can conserve water and so help maintain the stability of the antioxidant system.

\section{Conclusions}

Drought stress can induce changes in the levels of many antioxidants in Z. bungeanum. Levels of POD, CAT, APX, proline and MDA all increased gradually under continuing drought, while that of SOD decreased. The expression levels of genes related to antioxidants was consistent with the changes in antioxidant content. Drought also activated genes relating to stomatal aperture, the ABA signaling pathway, the MAPK signaling pathway and the JA signaling pathway. 
between stress duration and stomatal aperture was best fitted by the exponential equation: $\mathrm{Y}=9.1529 \mathrm{e}^{-0.081 X}, \mathrm{R}^{2}=0.92$.

\section{Acknowledgements}

The authors would like to thank Yao Ma for his participation in the manuscript discussion. This study was financially supported by the National Key Research and Development Program Project Funding (2018YFD1000605).

\section{References}

1. Yang LC, Li R, Tan J, Jiang ZT. Polyphenolics composition of the leaves of Zanthoxylum bungeanum Maxim. grown in Hebei, China, and their radical scavenging activities. J Agric Food Chem. 2013;61(8):1772-8. doi: 10.1021/jf3042825. PubMed PMID: 23383696.

2. Zhang Y, Luo Z, Wang D, He F, Li D. Phytochemical profiles and antioxidant and antimicrobial activities of the leaves of Zanthoxylum bungeanum. ScientificWorldJournal. 2014;2014:181072. doi: 10.1155/2014/181072. PubMed PMID: 25147836; PubMed Central PMCID: PMCPMC4134800.

3. Zhang Z, Liu J, Shen P, Cao Y, Lu X, Gao X, et al. Zanthoxylum bungeanum pericarp extract prevents dextran sulfate sodium-induced experimental colitis in mice via the regulation of TLR4 and TLR4-related signaling pathways. Int Immunopharmacol. 2016;41:127-35. doi: 10.1016/j.intimp.2016.10.021. PubMed PMID: 27843005.

4. Zhang WJ, Guo SS, You CX, Geng ZF, Liang JY, Deng ZW, et al. Chemical Composition of Essential Oils from Zanthoxylum bungeanum Maxim. and Their Bioactivities against Lasioderma serricorne. J Oleo Sci. 2016;65(10):871-9. doi: 10.5650/jos.ess16038. PubMed PMID: 27628733.

5. Rong R, Cui MY, Zhang QL, Zhang MY, Yu YM, Zhou XY, et al. Anesthetic constituents of Zanthoxylum bungeanum Maxim.: A pharmacokinetic study. J Sep Sci. 2016;39(14):2728-35. doi: 10.1002/jssc.201600295. PubMed PMID: 27233468.

6. Gill SS, Tuteja N. Reactive oxygen species and antioxidant machinery in abiotic stress tolerance in crop plants. Plant Physiol Biochem. 2010;48(12):909-30. doi: 10.1016/j.plaphy.2010.08.016. PubMed PMID: 20870416.

7. N. GC, K. RS. Superoxide dismutases: I . Occurrence in higher plants. Plant Physiology. 1977;59(2):309-14.

8. Chance. B, Maehly. AC. Assay of catalases and peroxidases. Methods in Enzymology. 1955;2:764-75.

9. Lima CS, Ferreira-Silva SL, Carvalho FEL, Lima Neto MC, Aragão RM, Silva EN, et al. Antioxidant protection and PSII regulation mitigate photo-oxidative stress induced by drought followed by high light in cashew plants. Environmental and Experimental Botany. 2018;149:59-69. doi: 10.1016/j.envexpbot.2018.02.001.

10. Li J, Li Y, Yin Z, Jiang J, Zhang M, Guo X, et al. OsASR5 enhances drought tolerance through a stomatal closure pathway associated with ABA and H2 O2 signalling in rice. Plant Biotechnol J. 2017;15(2):183-96. doi: 10.1111/pbi.12601. PubMed PMID: 27420922; PubMed Central PMCID: PMCPMC5258865.

11. Martin-StPaul N, Delzon S, Cochard H. Plant resistance to drought depends on timely stomatal closure. Ecol Lett. 2017;20(11):1437-47. doi: 10.1111/ele.12851. PubMed PMID: 28922708. 
12. Garci'a-Mata. C, Lamattina. L. Nitric Oxide Induces Stomatal Closure and Enhances the Adaptive Plant Responses against Drought Stress. Plant Physiology. 2001;126:1196-204.

13. Cornic. G. Drought stress inhibits photosynthesis by decreasing stomatal aperture--not by affecting ATP synthesis. Trends in Plant Science. 2000;5(5):187-8.

14. Panchuk, II, Volkov RA, Schoffl F. Heat stress- and heat shock transcription factor-dependent expression and activity of ascorbate peroxidase in Arabidopsis. Plant Physiol. 2002;129(2):838-53. doi: 10.1104/pp.001362. PubMed PMID: 12068123; PubMed Central PMCID: PMCPMC161705.

15. Fu. J, Huang. B. Involvement of antioxidants and lipid peroxidation in the adaptation of two cool-season grasses to localized drought stress. Environmental and Experimental Botany. 2001;45:105-14. doi: 10.1016/S0098-8472(00)00084-8.

16. Bates LS, Waldren RP, Teare ID. Rapid determination of free proline for water-stress studies. Plant Soil. 1973;39:205-7.

17. Fei X, Shi Q, Yang T, Fei Z, Wei A. Expression Stabilities of Ten Candidate Reference Genes for RT-qPCR in Zanthoxylum bungeanum Maxim. Molecules. 2018;23(4). doi: 10.3390/molecules23040802. PubMed PMID: 29601541; PubMed Central PMCID: PMCPMC6017173.

18. von Groll U. The Subtilisin-Like Serine Protease SDD1 Mediates Cell-to-Cell Signaling during Arabidopsis Stomatal Development. The Plant Cell Online. 2002;14(7):1527-39. doi: 10.1105/tpc.001016.

19. Zhang X, Zhao Y, Wang S. Responses of antioxidant defense system of epilithic mosses to drought stress in karst rock desertified areas. Acta Geochimica. 2017;36(2):205-12. doi: 10.1007/s11631-017-0140-z.

20. Dalvi US, Naik RM, Lokhande PK. Antioxidant defense system in chickpea against drought stress at pre- and postflowering stages. Indian Journal of Plant Physiology. 2017;23(1):16-23. doi: 10.1007/s40502-017-0322-z.

21. Tina RR, Shan XR, Wang Y, Guo SY, Mao B, Wang W, et al. Response of antioxidant system to drought stress and re-watering in Alfalfa during branching. IOP Conference Series: Earth and Environmental Science. 2017;94:012129. doi: 10.1088/1755-1315/94/1/012129.

22. Mittler. R, Zilinskas. BA. Regulation of pea cytosolic ascorbate peroxidase and other antioxidant enzymes during the progression of drought stress and following recovery from drought. The Plant Journal. 1994;5(3):397-405.

23. Sharma P, Dubey RS. Drought Induces Oxidative Stress and Enhances the Activities of Antioxidant Enzymes in Growing Rice Seedlings. Plant Growth Regulation. 2005;46(3):209-21. doi: 10.1007/s10725-005-0002-2.

24. Bian S, Jiang Y. Reactive oxygen species, antioxidant enzyme activities and gene expression patterns in leaves and roots of Kentucky bluegrass in response to drought stress and recovery. Scientia Horticulturae. 2009;120(2):264-70. doi: 10.1016/j.scienta.2008.10.014.

25. FAZELI. F, GHORBANLI. M, NIKNAM. V. Effect of drought on biomass, protein content, lipid peroxidation and antioxidant enzymes in two sesame cultivars. Biologia Plantarum. 2007;51(1):98-103.

26. Zhao. Z, Chen. G, Zhang. C. Interaction between reactive oxygen species and nitric oxide in drought-induced abscisic acid synthesis in root tips of wheat seedlings. Australian Journal of Plant Physiology. 2001;28:1055-61.

27. Kurusu T, Kuchitsu K, Tada Y. Plant signaling networks involving $\mathrm{Ca}(2+)$ and Rboh/Nox-mediated ROS production under salinity stress. Front Plant Sci. 2015;6:427. doi: 10.3389/fpls.2015.00427. PubMed PMID: 26113854; PubMed Central PMCID: PMCPMC4461821.

28. Duan ZQ, Bai L, Zhao ZG, Zhang GP, Cheng FM, Jiang LX, et al. Drought-stimulated activity of plasma membrane nicotinamide adenine dinucleotide phosphate oxidase and its catalytic properties in rice. J Integr Plant Biol. 2009;51(12):1104-15. doi: 10.1111/j.1744-7909.2009.00879.x. PubMed PMID: 20021558.

29. Miller. G, Schlauch. K, Tam. R, Cortes. D, Torres. MA, Shulaev. V, et al. The Plant NADPH Oxidase RBOHD Mediates Rapid Systemic Signaling in Response to Diverse Stimuli. Science Signaling. 2009;2(84):ra45. doi: 10.1126/scisignal.2000448]. 
30. Wang Y, Branicky R, Noe A, Hekimi S. Superoxide dismutases: Dual roles in controlling ROS damage and regulating ROS signaling. J Cell Biol. 2018;217(6):1915-28. doi: 10.1083/jcb.201708007. PubMed PMID: 29669742; PubMed Central PMCID: PMCPMC5987716.

31. Strizhov. N, braha'm. EA, sz. LsOk, Blickling. S, Zilberstein. A, Schell. J, et al. Differential expression of two P5CS genes controlling proline accumulation during salt-stress requires ABA and is regulated by ABA1, ABI1 and AXR2 in Arabidopsis. The Plant Journal. 1997;12(3):557-69.

32. Qi. W, Zhang. L, Feng. W, Xu. H, Wang. L, Jiao. Z. ROS and ABA Signaling Are Involved in the Growth Stimulation Induced by Low-Dose Gamma Irradiation in Arabidopsis Seedling. Applied Biochemistry and Biotechnology. 2015;175:1490-506. doi: 10.1007/s12010-014-1372-6).

33. He F, Wang HL, Li HG, Su Y, Li S, Yang Y, et al. PeCHYR1, a ubiquitin E3 ligase from Populus euphratica, enhances drought tolerance via ABA-induced stomatal closure by ROS production in Populus. Plant Biotechnol J. 2018;16(8):1514-28. doi: 10.1111/pbi.12893. PubMed PMID: 29406575; PubMed Central PMCID: PMCPMC6041450. 34. Lim IK, Choi JA, Kim EY, Kim BN, Jang S, Ryu MS, et al. TIS21(/BTG2) inhibits doxorubicin-induced stress fiber-vimentin networks via Nox4-ROS-ABI2-DRF-linked signal cascade. Cell Signal. 2017;30:179-90. doi: 10.1016/j.cellsig.2016.12.001. PubMed PMID: 27932314.

35. Singh R, Parihar P, Singh S, Mishra RK, Singh VP, Prasad SM. Reactive oxygen species signaling and stomatal movement: Current updates and future perspectives. Redox Biol. 2017;11:213-8. doi: 10.1016/j.redox.2016.11.006. PubMed PMID: 28012436; PubMed Central PMCID: PMCPMC5192041.

36. Vahisalu T, Kollist H, Wang YF, Nishimura N, Chan WY, Valerio G, et al. SLAC1 is required for plant guard cell S-type anion channel function in stomatal signalling. Nature. 2008;452(7186):487-91. doi: 10.1038/nature06608. PubMed PMID: 18305484; PubMed Central PMCID: PMCPMC2858982.

37. Zou JJ, Wei FJ, Wang C, Wu JJ, Ratnasekera D, Liu WX, et al. Arabidopsis calcium-dependent protein kinase CPK10 functions in abscisic acid- and Ca2+-mediated stomatal regulation in response to drought stress. Plant Physiol. 2010;154(3):1232-43. doi: 10.1104/pp.110.157545. PubMed PMID: 20805328; PubMed Central PMCID: PMCPMC2971602.

38. Kneeshaw. S, Keyani. R, Delorme-Hinoux. V, Imrie. L, Loake. GJ, Bihan. TL, et al. Nucleoredoxin guards against oxidative stress by protecting antioxidant enzymes. PNAS. 2017;114(31):8414-9. 

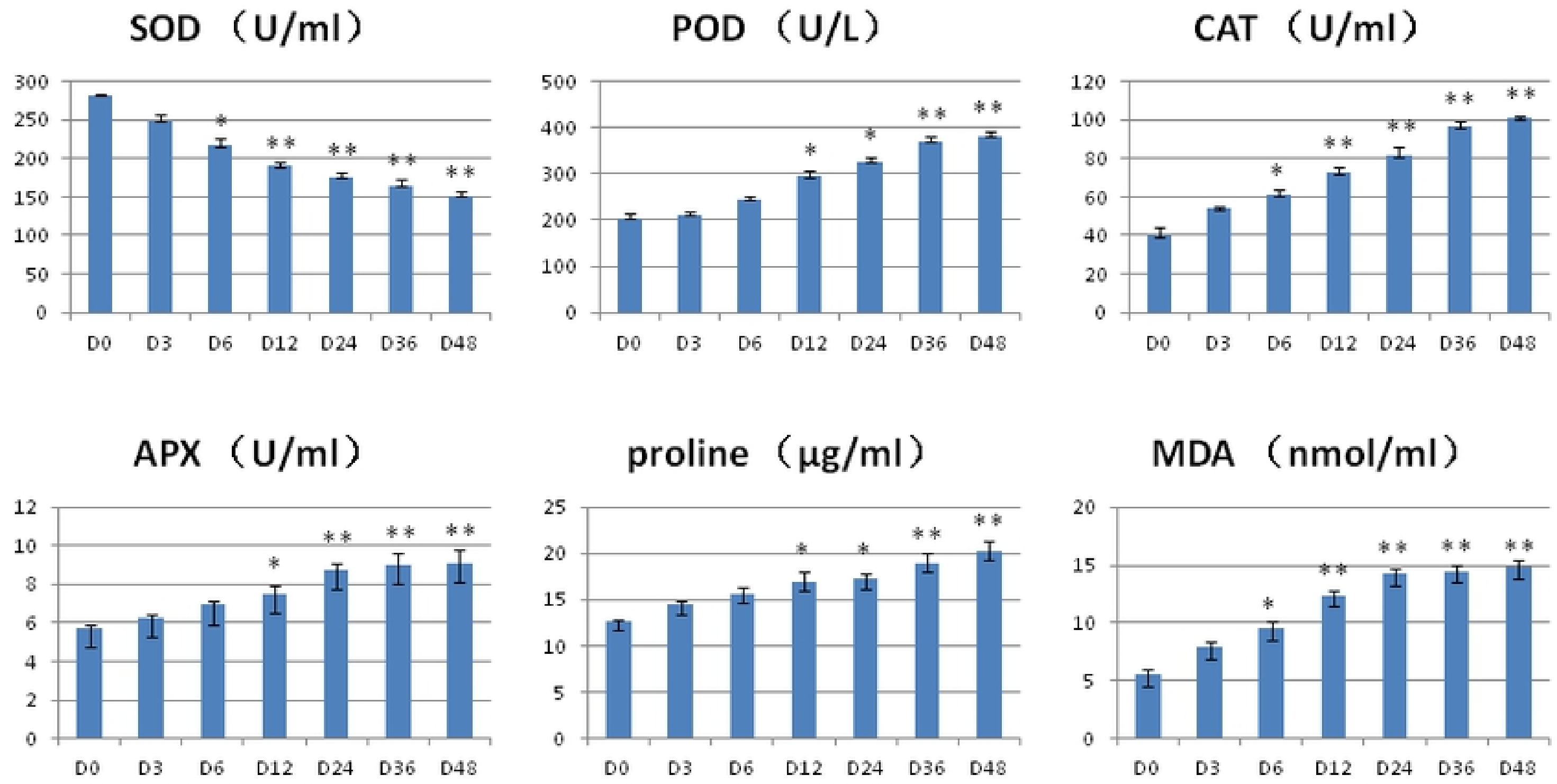

Figure 1 

SOD1

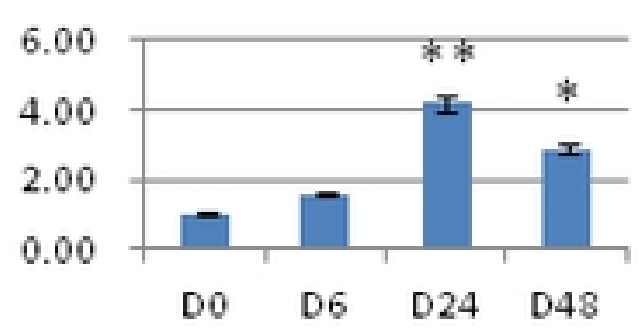

APX3

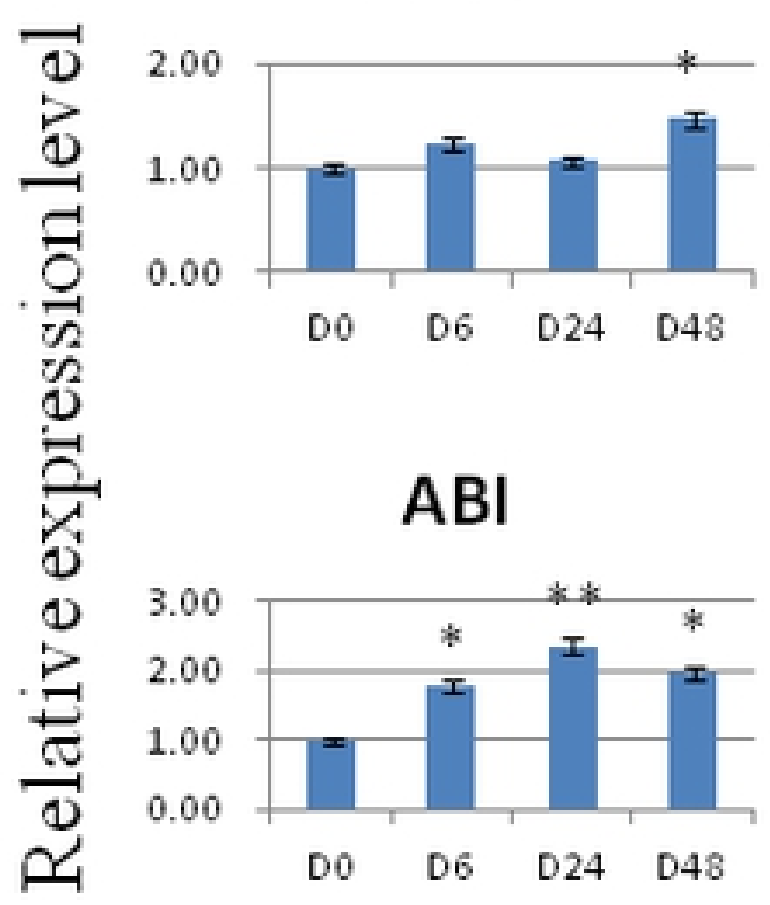

NRX1

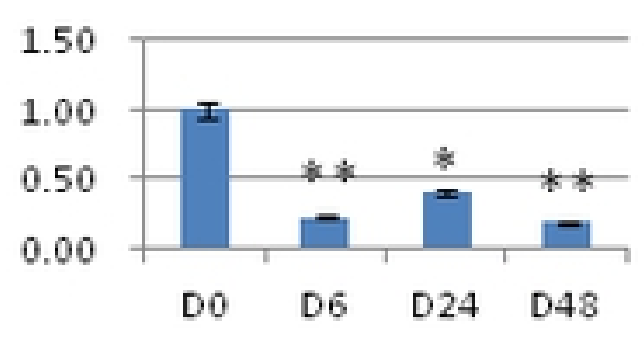

SOD2

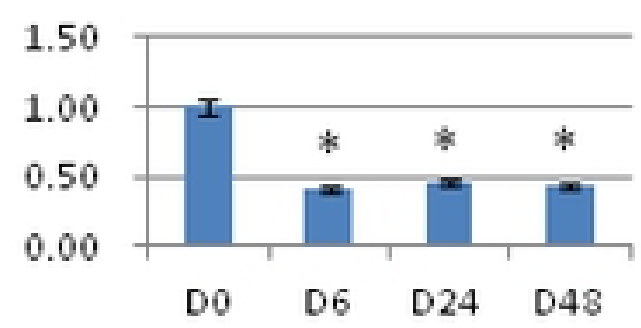

GPX1

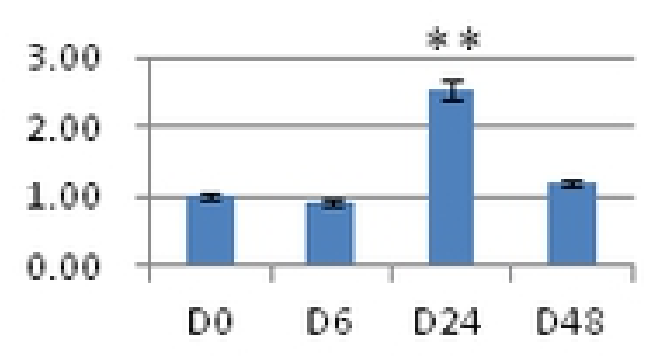

MAPK1

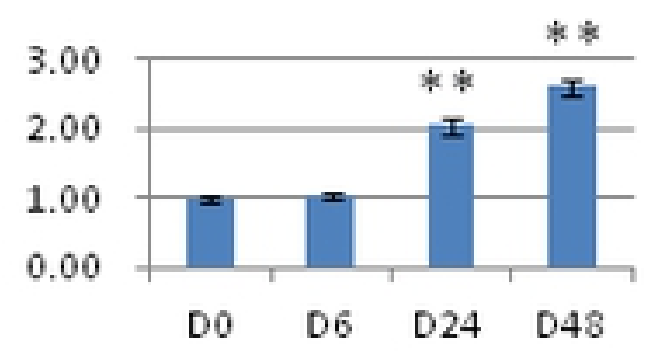

EPFL9

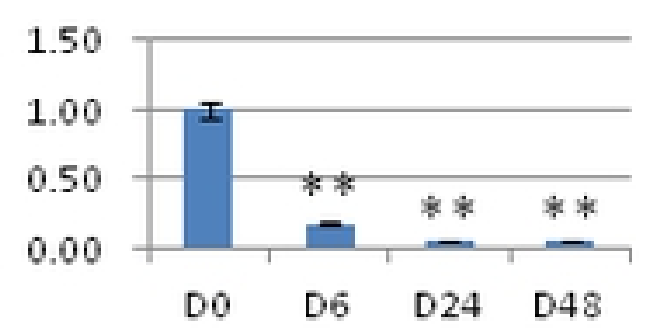

PRX2E

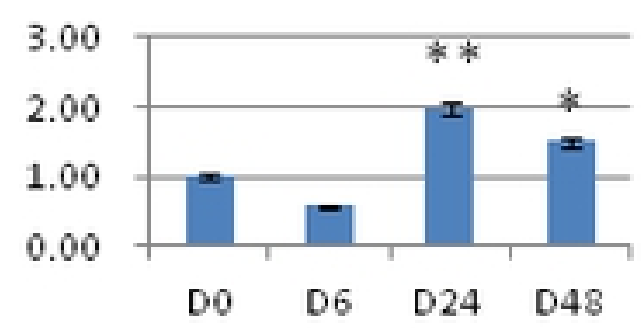

P5CS

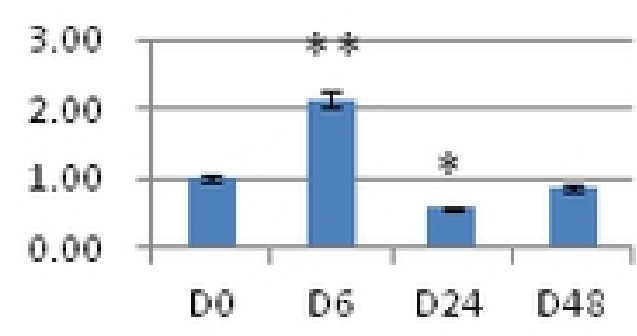

PDI52

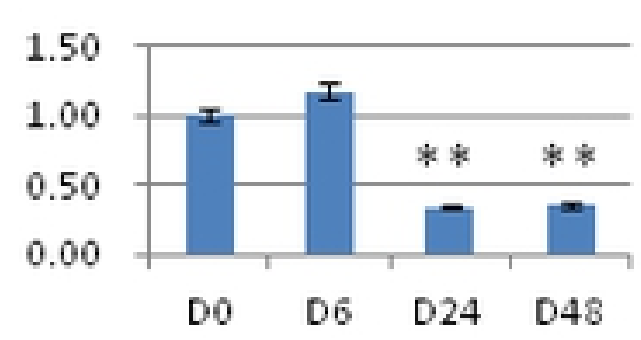

TCTP

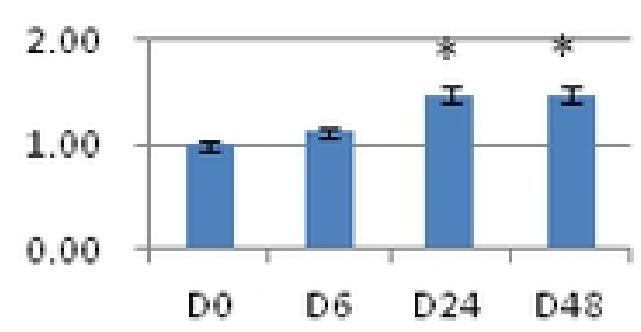

CAT

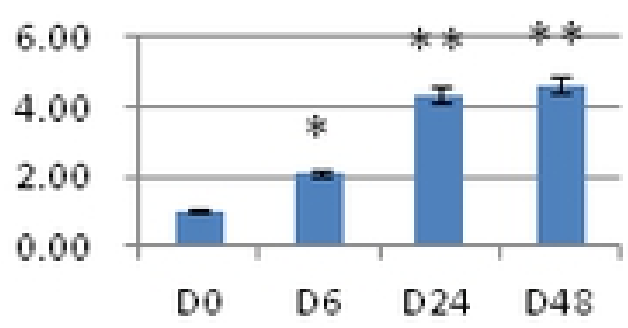

JAR1

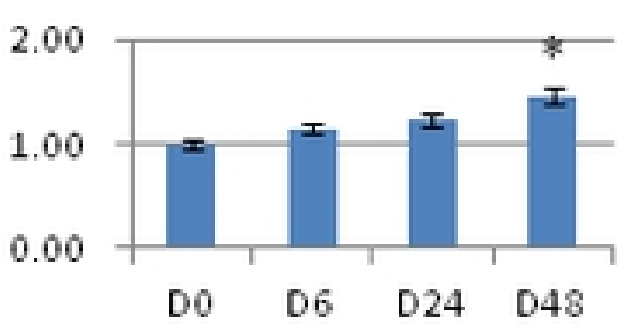

NOX

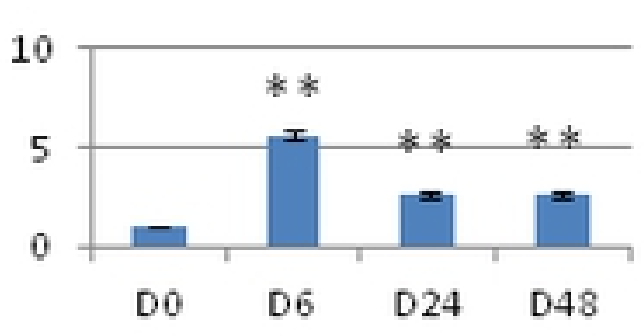

RBOHC

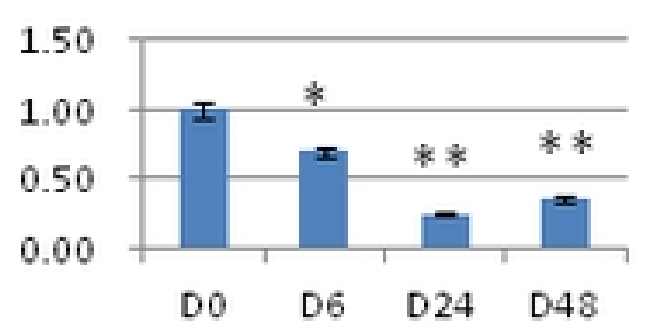

Figure 3 

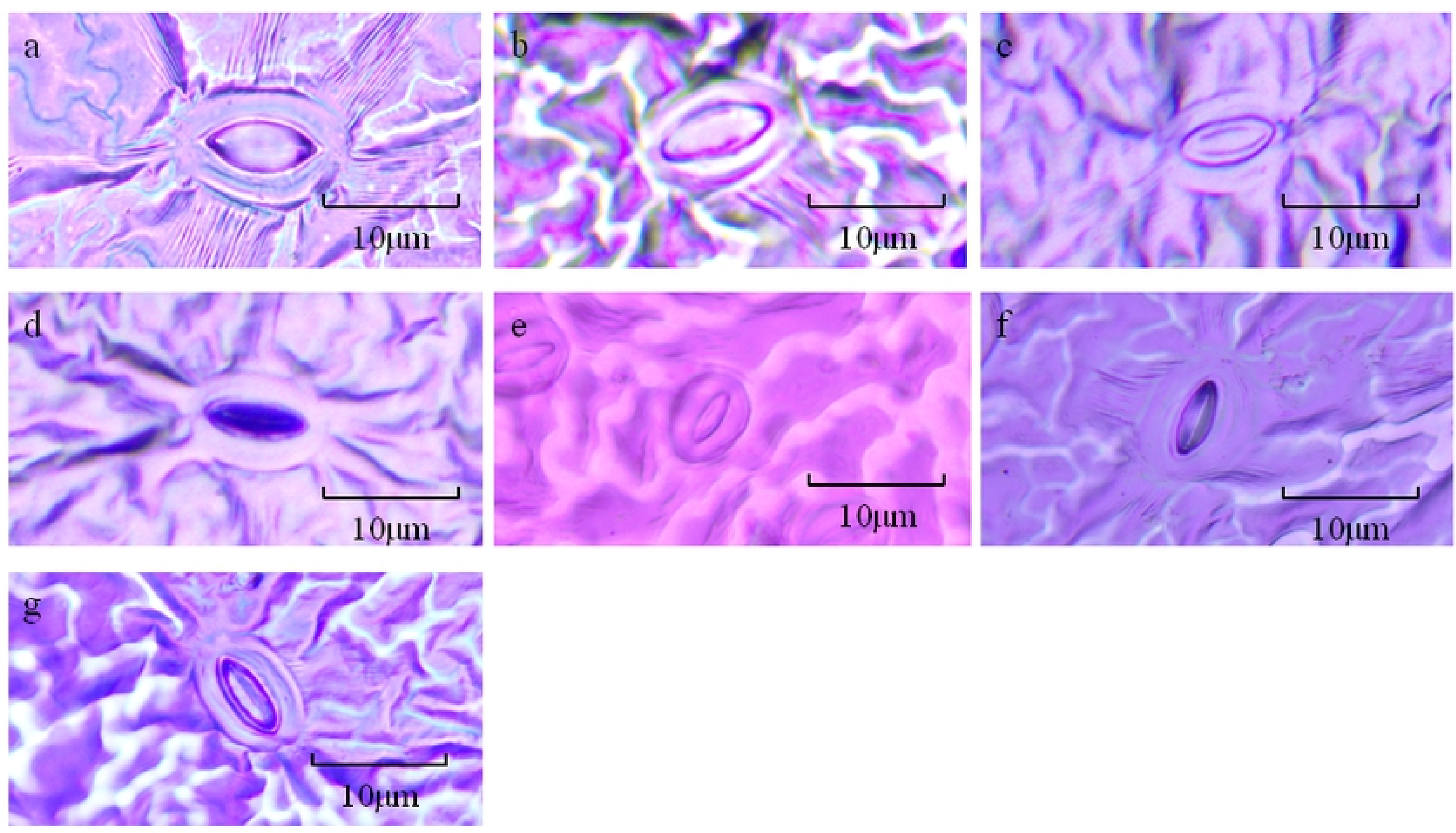

Figure 4 


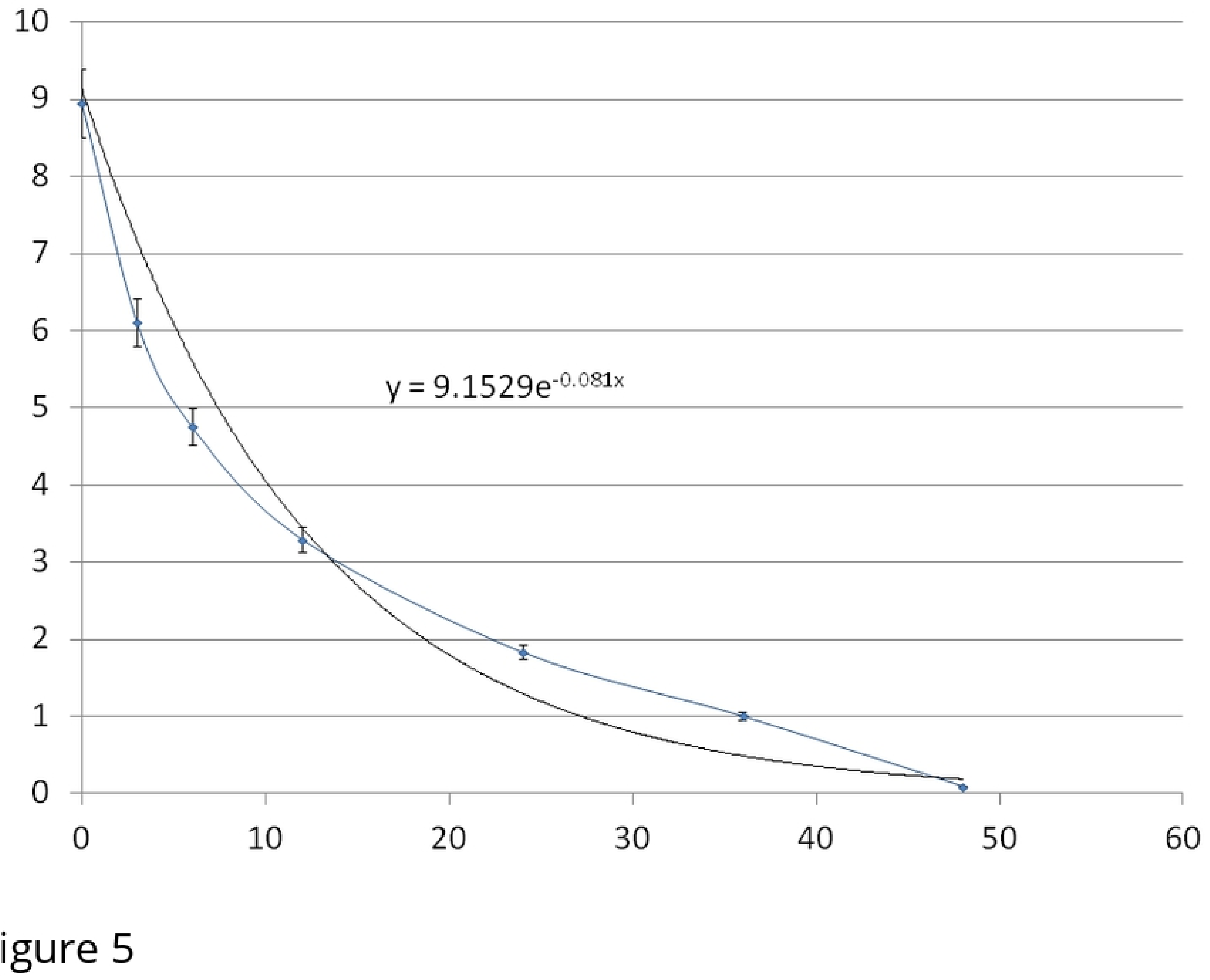




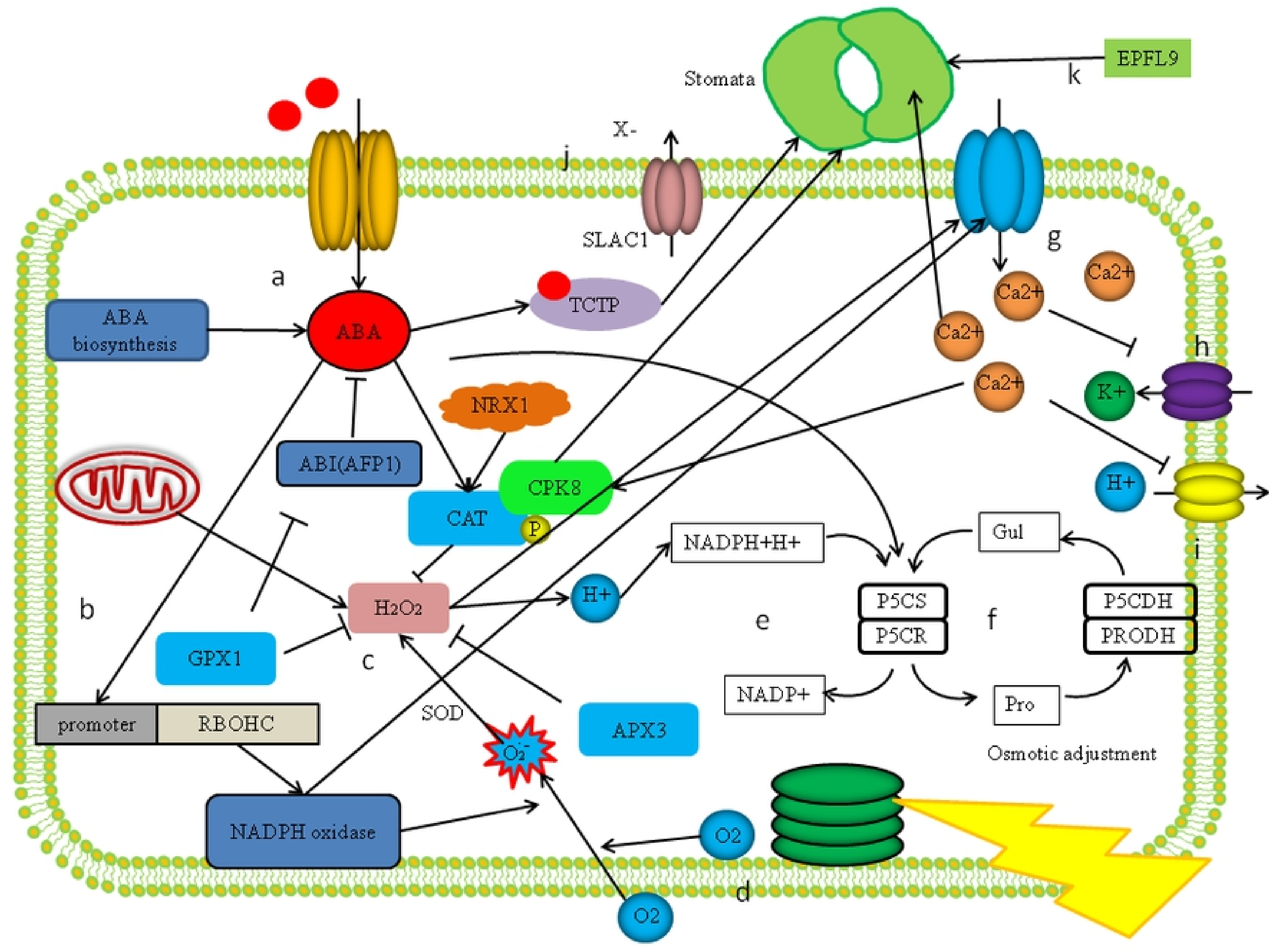

Figure 6 